\title{
Emerging Organic Contaminants in Groundwater
}

\author{
Marianne Stuart and Dan Lapworth \\ British Geological Survey, Wallingford, OX10 8BB UK \\ *Email: mest@bgs.ac.uk
}

\begin{abstract}
Emerging organic contaminants (ECs) are compounds now being found in groundwater from agricultural, urban sources that were previously not detectable, or thought to be significant. ECs include pesticides and degradates, pharmaceuticals, industrial compounds, personal care products, fragrances, water treatment byproducts, flame retardants and surfactants, as well as 'life-style' compounds such as caffeine and nicotine. ECs may have adverse effects on aquatic ecosystems and human health. Frequently detected ECs include the anti-epileptic drug carbamazepine, the antibiotic sulfamethoxazole, the anti-inflammatories ibuprofen and diclofenac, and caffeine, as well as pesticide degradates. This means there will be challenges in the future in order to address these ECs and to minimise their impact on drinking water and ecosystems. In the coming decades, more ECs are likely to have environmental standards defined, and therefore a better understanding of environmental behaviour remains a priority.
\end{abstract}

\section{Keywords}

Emerging contaminants; groundwater; pharmaceuticals; pesticide degradates; personal care products

\section{$1 \quad$ Introduction}

A diverse array of synthetic organic compounds is used worldwide in large quantities for the production and preservation of food, for industrial manufacturing processes and for human and animal healthcare. In the last few decades there has been a growing interest in the occurrence of these contaminants in the terrestrial and aquatic environment, their environmental fate and their potential toxicity even at low concentrations [1-6]. The contamination of groundwater resources is a growing concern and relatively poorly understood compared to other freshwater resources [7]. 
Organic compounds previously not considered or known to be significant in groundwater in terms of distribution and/or concentration, which are now being more widely detected and which have the potential to cause known or suspected adverse ecological or human health effects are here referred to as emerging contaminants (ECs). Synthesis of new chemicals or changes in use and disposal of existing chemicals can create new ECs. ECs also include substances that have long been present in the environment but whose presence and significance are only now being elucidated [8]. As analytical techniques improve, previously undetected organic micro-contaminants are being observed in the aqueous environment [9-10]. Richardson and Ternes (2011) review recent analytical developments in the emerging contaminant context [11].

ECs include a wide array of different compounds (as well as their metabolites and transformation products, collectively referred to here as degradates) including; pharmaceuticals and personal care products (PCPs), pesticides, veterinary products, industrial compounds/by-products, food additives as well as engineered nanomaterials. Because of the vast number of possible compounds, many studies have selected ECs according to priority lists established taking into account consumption, predicted environmental concentrations as well as ecotoxicological, pharmacological and physicochemical data [12-17].

To date, the occurrence of ECs has been much better characterised in wastewater and surface water environments than in groundwater [7]. Wastewaters are the main sources of ECs in the environment and surface waters therefore contain the greatest loads of ECs. Wastewaters and surface waters are also thought to contain a much greater diversity of compounds compared to groundwater, although this may be simply a function of the capability of analytical methods relative to the generally lower groundwater concentrations and the limited number of groundwater studies.

The occurrence of ECs in surface waters has been reviewed for public water supply [18], for sources to public supplies, [7], and for occurrence and fate of ECs and established trace pollutants [19]. The first systematic review of ECs in groundwater, by Lapworth et al. (2012), highlighted the worldwide widespread contamination of groundwater resources by a large variety compounds that are detected as a result of both recent and historical activities [20]. Environmentally significant concentrations $\left(10^{2}-10^{4} \mathrm{ng} / \mathrm{L}\right)$ of a range of ECs, including a number of endocrine disrupting substances, are being detected in groundwaters globally. Many of these ECs are among the highest priority substances for treatment and regulation both in terms of their potential environmental and human health effects.

Many ECs remain unregulated and present analytical and institutional challenges [21]. The number of regulated contaminants will continue to grow slowly over the 
coming decades. Monitoring of anthropogenic micro-organic pollutants in river basins is required within the framework of various national regulations [22-23] with the overall aim of protecting and improving the quality of water resources.

In the European context groundwater quality is currently regulated under the Water Framework Directive (WFD) [24], its daughter Groundwater Directive (GD) [22] and drinking water under the Drinking Water Directive [25]. Pesticides are also regulated under the Plant Protection and Biocides Directives [26-27]. The WFD and the GD establish environmental objectives for protecting groundwater and water bodies and groundwater dependant ecosystems. These require that threshold values (standards) be established for pollutants that put the groundwater body at risk of failing to achieve its environmental objectives. Whilst for many chemical pollutants there is sufficient knowledge to establish threshold values, in the case of most ECs the current lack of knowledge on toxicity, impact, behaviour and limited monitoring data mean that threshold values cannot yet be set.

The European Drinking Water Directive sets limits for a small number of organic micropollutants comprising aromatic hydrocarbons, chlorinated solvents and disinfection by-products [25]. Priority substances established under another WFD daughter directive include benzene, octyl and nonyl phenols, specified polyaromatic hydrocarbons (PAH), di(2-ethylhexyl)phthalate and a range of chlorinated hydrocarbons[28]. The European Commission aims to table draft limits for 16 new substances limits under the WFD including anti-inflammatory drugs, synthetic contraceptives and perfluorooctane sulfonate (PFOS) [29].

A similar situation occurs elsewhere in the world. Regulatory frameworks exist to manage the potential sources of pollution and require monitoring of a number of 'priority' organic contaminants in the aquatic environment. However, there are a huge number of contaminants (largely organic compounds) that are not subject to the same degree of regulation at present (for the same reasons outlined above). The US Environment Protection Agency (EPA) have derived statutory guideline values for about 125 contaminants in drinking water of which 31 could be considered to be micro-organic pollutants excluding pesticides. None of these are pharmaceuticals or PCPs [30]. The US EPA published a new contaminant candidate list (CCL-3) in 2009 which included 3 pharmaceuticals as well as perfluorooctanoic acid (PFOA), PFOS and eight hormones [10].

\section{Types of Emerging Groundwater Contaminants}

Much more is known about pesticides in groundwater compared to other compounds, such as pharmaceuticals, which are more poorly characterised. The hazards to human health of some compounds are well documented, but their ability to travel 
through the aqueous environment is only just being investigated, and environmental persistence is as yet unknown. From their sources, physical and chemical characteristics, mobility/behaviour in the aqueous environment and associated hazards the following types of micro-contaminants may be considered to be emerging in groundwater.

\section{$2.1 \quad$ Pesticides}

Pesticides have been detected at trace concentrations in groundwater worldwide for a considerable period and are well-established contaminants. By the 1990s atrazine, simazine and a range of other herbicides had been found in groundwater worldwide [31-36]. Recently new detections of parent compounds have become apparent as analytical methods have improved, for example metaldehyde in the UK [37], and this also fits the emerging contaminant definition.

Even twenty years ago it was clear that pesticide degradates needed to be considered [38-39]. Some studies have even shown that pesticide metabolites may be detected in groundwater at higher concentrations compared to parent compounds from both agricultural and amenity use [40-41]. By their nature degradates are biologically active and many may be toxic, and such data forms part of the pesticide registration process although they are still often not adequately monitored.

\subsection{Pharmaceuticals}

The presence of pharmaceutical chemicals in the aquatic environment has long been recognised as a concern [42]. The primary routes for pharmaceuticals into the environment are through human excretion, disposal of unused products and through agricultural usage [43]. A wide range of pharmaceutical products have been detected in surface and groundwater, associated with wastewater disposal [44-48]. These have included:

- veterinary and human antibiotics: ciprofloxacin, clofibric acid, lincomycin, sulfamethoxazole, tetracycline

- other prescription drugs: carbamazepine, codeine, diclofenac, salbutamol,

- non prescription drugs: acetaminophen (paracetamol), ibuprofen, salicylic acid

- iodinated X-ray contrast media: iopromide, iopamidol

Other potential threats to surface water which have been identified are tamiflu and chemotherapy drugs, such as 5-fluorourcil, ifosfamide or cyclophosphamide [4952] and illicit drugs such as cocaine and amphetamines [53-54]. 


\section{3 "Life-style" Compounds}

Caffeine, nicotine and the nicotine metabolite cotinine have been widely detected in groundwater impacted by sewage effluent [55-57]. The artificial sweeteners acesulfame, saccharine, cyclamate and sucralose have been found at high concentrations in groundwater impacted by sewage infiltration ponds [58]. Buerge et al. (2009) showed acesulfame to be widely detected in the aquatic environment due to its use, mobility and persistence [59].

\subsection{Personal Care Compounds}

PCPs contain a wide range of compounds are commonly transmitted to the aqueous environment through sewage treatment works. These have included:

- N,N-diethyl-meta-toluamide (DEET), the most common active ingredient in insect repellents

- parabens - alkyl esters of p-hydroxybenzoic acid, used since the 1930s as bacteriostatic and fungistatic agents in drugs, cosmetics, and foods

- bacteriocide and antifungal agents - triclosan is widely used in household products, such as toothpaste, soap and anti-microbial sprays

- polycyclic musks - tonalide and galoxalide are used as fragrances in a wide range of washing and cleaning agents and PCPs

- UV filters/sunscreen - organic filters include the benzophenones and methoxycinnamates

Lindström et al. (2002) detected triclosan and its metabolite methyl triclosan in surface water in Switzerland, and considered the metabolite to be persistent [60]. Tonalide (AHTN), galoxalide (HHCB) and HHCB-lactone have been detected in wastewater [61] and these compounds have been used as markers for wastewater in surface waters [62-63]. Heberer (2002) discussed the results from investigations of synthetic musk compounds found in sewage, sewage sludge, surface water, aquatic sediment, and biota samples in terms of bioaccumulation, metabolism in fish, and environmental and human risk assessment [64]. The majority of compounds used as sun screens are lipophilic, conjugated aromatic compounds, but are still detected in the aqueous environment [65].

\subsection{Industrial Additives and By-products}

There are a wide range of industrial compounds which can be released to the environment and many of these have led to well-established problems. Examples include chlorinated solvents, petroleum hydrocarbons, including polyaromatic hydrocarbons and the fuel oxygenate methyl tertiary-butyl ether, and plasticisers/resins bisphenols, adipates and phthalates [65-69]. Most of these 
industrial compounds are classed as priority pollutants or now have drinking water limits and as such are not emerging contaminants. However, some breakdown products may be regarded as emerging contaminants. Industrial ECs may include:

- 1,4-dioxane, a 1,1,1,-trichloroethane stabiliser which is soluble in water, resistant to biodegradation, does not readily bind to soils, and readily leaches [70]

- Benzotriazole derivatives which are found in antifungal, antibacterial, and antihelmintic drugs and are persistent in the aqueous environment [71-72]

- Dioxins produced as a consequence of degradation of other micropollutants e.g. from the antimicrobial additive triclosan [73-74]

\section{$2.6 \quad$ Food Additives}

Some food additives are considered to be oxidants or endocrine disruptors [75]. Triethyl citrate is used as a food additive to stabilise foams as well as for pharmaceutical coatings, and is also a plasticiser. Butylated hydroxyanisole and hydroxytoluene are used to preserve fat in foods. Other food additives include camphor, 1,8-cineole (eucalyptol), citral, citronellal, cis-3-hexenol, heliotropin, phenylethyl alcohol, triacetin, and terpineol.

\subsection{Water Treatment By-products}

The trihalomethanes and haloacetic acids are well established by-products of water disinfection [76]. More recent concern has focused on N-nitrosodimethylamine (NDMA) as a drinking water contaminant resulting from reactions occurring during chlorination or from direct industrial contamination. Because of the relatively high concentrations of this potent carcinogen formed during wastewater chlorination, the intentional and unintentional reuse of municipal wastewater is a particularly important area [77]. The change from disinfection with chlorine to ozone and chloramines can increase levels of other potentially toxic by-products [42]. Other by products of water treatment can include polyacrylamide and epichlorhydrin [74].

\section{$2.8 \quad$ Flame/Fire Retardants}

Polybrominated diphenyl ether flame retardants are extensively used in resins for household and industrial use [78], and may enter the environment via waste disposal to landfill and incineration. Phosphate-based retardants such tris-(2-chloroethyl) phosphate appear to work by forming a non-flammable barrier are used in industrial and consumer products [79].

\subsection{Surfactants}

A range of anionic, cationic, amphoteric and non-ionic surfactants and antifoaming agents are commonly found in wastewater [80]. The priority pollutants octyl- and 
nonyl-phenol (OP and NP) are used in the production of alkyl phenol ethoxylates (APEs) for the manufacture of non-ionic surfactants. Both the parent ethoxylates and their metabolites, alkyl phenols and carboxylic degradation products, have been shown to persist in the aquatic environment [81-82]. Non-ionic polyethylene glycolbased compounds are used as anti-foaming agents. Siloxanes are used in many PCPs as anti foaming agents and there is concern about their potential toxicity and transport in the aquatic environment [83].

Cationic surfactants include quaternary ammonium salts, such as cetrimonium chloride, are used as emulsifiers, antiseptics and homologues have been identified as emerging contaminants in marine sediments [84]. Amphoteric surfactants include coconut-based products such as the widely used cocamidopropyl betaine. Anionic surfactants, including perfluorinated compounds such as PFOS and PFOA, have been used for over 50 years in food packaging and cookware coatings, paints and surfactants, cosmetics and fire-fighting foams. They are found in wastewater and surface water and are very persistent in the environment [85-86]. PFOS was found in sewage effluent in Japan and has also been detected in surface water [87-88].

\subsection{Hormones and Sterols}

Sex hormones include androgens, such as androstenedione and testosterone, and estrogens such as estrone, estriol, $17 \alpha-$ and $17 \beta$-estrodiol, and progesterone. There are also synthetic androgens such as nandrolone and more importantly synthetic estrogens (xenoestrogens) such as $17 \alpha$-ethinylestrodiol and diethylstilbestrol, widely used as contraceptives. Some of these compounds are commonly present in wastewater and treated effluent [47, 89-90]. A related group of compounds are cholesterol and its metabolite $5 \beta$-coprostanol, and the plant sterols stigmastanol, stigmasterol and $\beta$-sitosterol. Plant sterols (phytoestrogens) are ingested from plants and excreted to wastewater, which may be the largest source of these compounds in the environment [91].

\subsection{Ionic Liquids}

Ionic liquids are salts with a low melting point which are being considered as 'green' replacements for industrial volatile compounds [10,92]. These compounds have nitrocyclic rings (e.g. pyridinium, pyrrolidinium or morpholinium moieties) or are quaternary ammonium salts. Ionic liquids are not yet widely used but current formulations have significant water solubility and are likely to be toxic and poorly degradable [92]. 


\subsection{Concepts}

The transport of contaminants in the aqueous environment can be described by a source-pathway-receptor model, which considers the source of the contaminant, the pathway by which it travels from the source and the receptor. Fig. 1 shows this approach for groundwater pollution by ECs. For many ECs the pathway from the source to the receptor is unclear, since there is a paucity of information for such contaminants. Direct pathways for urban and industrial contaminants, and pharmaceuticals, to reach groundwater include leaking sewers, discharge of effluent (directly to ground or to surface water which then infiltrates), landfill leachate, leaking storage tanks and discharges to the ground bypassing the soil zone, such as septic tanks (Fig. 1). Pathways to humans and groundwater from human and animal pharmaceuticals have been proposed [3, 94-95]. Compounds which pose a threat include those which remain difficult to analyse for at low concentrations and those which have physicochemical properties which allow them to persistent during and after drinking water treatment.

\subsection{Diffuse Source Terms}

Diffuse (non-point-source) pollution originates from poorly-defined sources that typically occur over broad geographical scales. For example, the majority of pesticide applications have been for agriculture and horticulture. Once released pesticides may be degraded by both biotic and abiotic processes. Stuart et al. (2012) discuss risk assessment approaches for pesticide degradates [96].

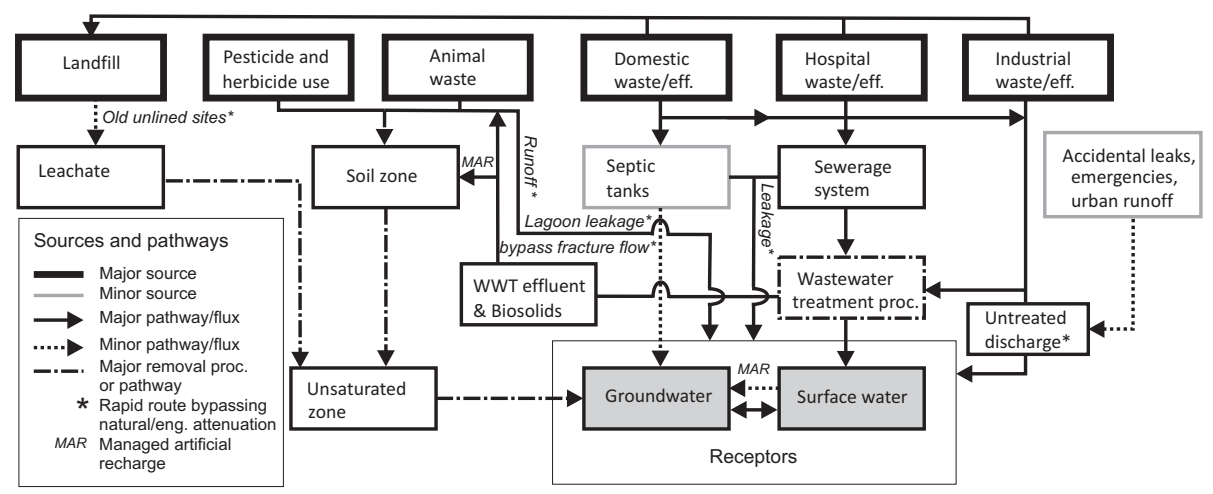

Fig 1. Source pathway receptor approach for ECs (after Lapworth et al. 2012)[20] 
Contaminants applied to the soil surface can migrate through the soil and unsaturated zones to groundwater. The practice of applying bio-solids to soil is and will continue to be a critical part of current global waste management practices. Application of manure, and bio-solids from sewage sludge processing has the benefit of enhancing soil nutrient levels, but the incomplete removal of ECs during wastewater treatment may result in residual concentrations in the solids [97]. These are likely to continue to be important potential sources of EC contamination in groundwater. Halogenated hydrocarbons (perflurochemicals and polychlorinated alkanes) can be important groundwater contaminants due to their relatively high concentrations in sludge and high solubility [97]. Veterinary antibiotics, antimicrobials and saccharin have all been reported from soil manure applications [98-100].

However, manure and bio-solid-derived ECs are more likely to reach ground water in significant concentrations via indirect routes, such as runoff and surface water-groundwater (SW-GW) exchange, rather than downward migration, due to attenuation in the soil and unsaturated zone [20]. SW-GW interaction is therefore an important pathway. Surface waters contain higher concentrations, and a larger range of ECs than groundwaters reflecting the direct input from wastewater sources, short residence times and the limited dilution capacity of surface water compared to groundwater [101-102]. ECs have been used to great effect to trace SW-GW exchange processes and as markers of wastewater sources [59, 103-105]. SW-GW exchange is particularly important in aquifers below and adjacent to water courses, for example in shallow alluvial aquifers, which are important sources of drinking water in many parts of the world.

Managed aquifer recharge refers to the use of surface water (including treated wastewater) to recharge an aquifer artificially. It is useful in semi-arid regions where water resources are scarce, to replenish aquifers, or use them as natural treatment and temporary storage systems [103] However, artificial recharge can short-circuit natural attenuation mechanisms in the soil and subsurface leading to potential longterm contamination of groundwater resources. Similarly diffuse leakage from poorlymaintained, reticulated sewerage systems may pose a significant risk of EC pollution to groundwater in urban land use settings as it also by-passes natural attenuation mechanisms in the soil zone [106].

Non-volatile compounds can be be mobilised by the atmospheric transmission route and aerial sources, such as dust from industry, transport and agriculture provide a diffuse but low loading to the land surface and are not considered significant for groundwater pollution [107]. 


\subsection{Point Source Terms}

Point-source pollution originates from discrete sources whose inputs into aquatic systems can often be defined in a spatially explicit manner. Wastewater-derived from domestic, industrial, or hospital premises and waste disposal sites is considered one of the most important point sources of ECs in the aquatic environment [108110]. A large number of studies have investigated the fate of ECs in groundwater following infiltration of wastewaters (sewage, septic tank effluents and industrial) as well as contaminated surface water sources, and to date provides the largest body of research regarding the sources and fate of ECs in the subsurface [111-128]. Hospital waste water forms an important source for a range of ECs including pharmaceuticals, disinfectants and musks and iodised X-ray contrast media [42, 129-132]. Discharges from pharmaceutical manufacturing sites may also contribute [133].

Infiltration of treated wastewater to the subsurface continues to be a very important potential source of ECs in groundwater [134-136]. This is a particular problem when groundwater residence times are short and natural recharge is low as it poses a threat to adjacent groundwater bodies as well as surface water resources. This source is clearly a major input of ECs into the environment globally, especially in regions where waste water treatment is poorly regulated or rudimentary.

The use of veterinary antibiotics in concentrated animal feeding operations is an important source of contamination in the USA and parts of Europe and Asia [137]. Veterinary antibiotics have been investigated in waste lagoons, groundwater below lagoons, as well as shallow groundwater from areas where animal waste had been applied to fields [97-98, 137-141].

Landfill leachates contain large amounts of fatty acids, and can also contain a complex mixture of synthetic organic compounds such as caffeine, nicotine, phenols, sterols, PAH, chlorinated solvents and phthalates [142]. The presence of pharmaceuticals in groundwater beneath or downgradient of a landfill has been confirmed by several authors [143-146]. Two recent studies [99, 147] investigating the occurrence of groundwater down gradient of landfills detected a range of industrial compounds (detergents, antioxidants, fire retardants, plasticisers) as well as pharmaceuticals (antibiotics, anti-inflammatories, barbiturates), caffeine and the nicotine metabolite cotinine.

\subsection{Key Sources}

In addition to agriculture and horticulture, pesticides have been applied to amenity and transport sites. The persistence of atrazine and diuron, and their degradates, in groundwater in the UK for many years after it was withdrawn for non-agricultural use highlights the importance of these other sources [41, 148]. Parsons et al. (2008) 
carried out an assessment of risk from pesticide metabolites for both the US and the UK [149]. For the USA 33 degradates from the most used pesticides were identified with the top 17 coming from acetanilides or triazines and with diazinon the most significant from home and garden use and diuron from commercial/industrial use. Similarly for the UK the most significant degradates came from triazines, urons, flufenacet, dicamba and metaldehyde.

Fig. 2 summarises the maximum EC concentrations in groundwater derived from 69 published studies including pharmaceuticals and hormones, PCP and lifestyle compounds, food additives, surfactants and flame retardants. The data are divided on the basis of major sources; agricultural waste (waste lagoons and biosolids), landfill, septic tanks, waste water (industrial and municipal). Landfill sources have the highest median value for all ECs. Wastewater contaminated groundwater has the largest number of compounds and results but agricultural waste contaminated groundwater has both the smallest number of compounds and number of samples overall. While there are several compounds (carbamazepine, sulfamethoxazole, ibuprofen, caffeine and nonylphenol (NP)) that are found in groundwaters impacted by three different source types, no EC was reported in all four source types. To date wastewater sources have been better characterised than other sources. Some contaminants are more source specific (e.g. contrasting agents from hospitals and veterinary pharmaceuticals) and as such are easier to trace in the environment compared to contaminants with multiple potential sources (e.g. caffeine).

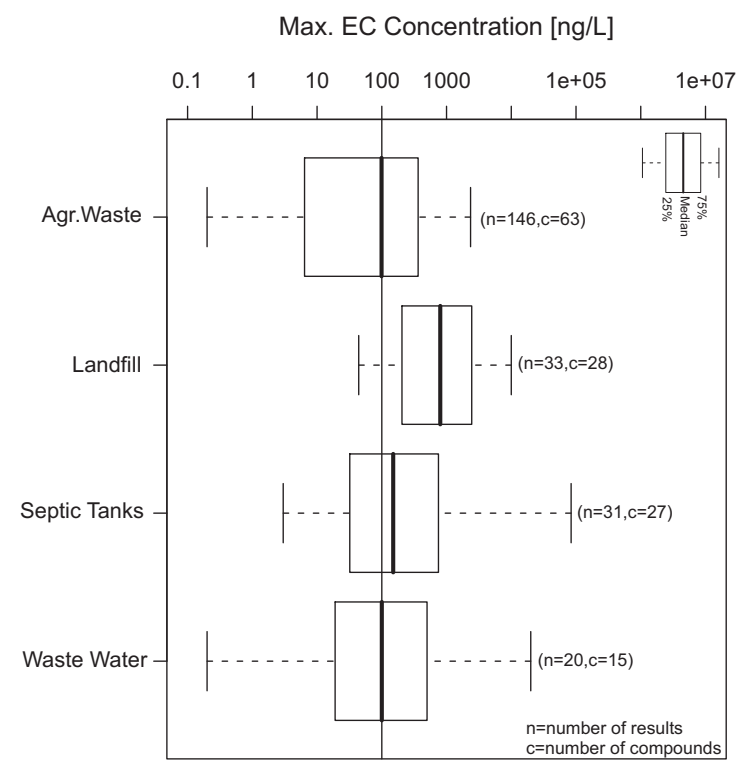

Fig 2. Key sources of ECs after Lapworth et al. (2012)[20] 


\section{$4 \quad$ Key Emerging Groundwater Contaminants}

Stuart et al. (2012) summarised a selection of European studies which reported pesticide degradates in groundwater [95]. In northern Europe as well as derivatives of atrazine, degradates from a range of herbicides including glyphosate, chloridazon, bentazone, diuron and metribuzin [39, 150-154]. In southern Europe and the USA the focus has been on the degradates of the acetanilide herbicides: acetochlor, alachlor and metolachlor [40, 155-159].

For other ECs Lapworth et al. (2012) summarised a large number of groundwater studies published since 1993 [20]. The maximum concentration for each compound was chosen for comparison as this was the most commonly cited value. While it is clear that the vast majority of groundwater resources do not contain ECs in concentrations that would be considered toxic and/or harmful, due to natural attenuation mechanisms, there is a large variety of ECs found in groundwater proximal to important direct and indirect sources (e.g. artificial recharge and surface water), and in some cases the concentrations are significant $(>100 \mathrm{ng} / \mathrm{L})$. The combined toxicity of multiple contaminants is not well understood at present [160]. A number of key ECs have a global footprint, and are frequently detected in groundwater resources. Fig. 3 shows box and whisker plots of maximum EC concentration in groundwater. Some groups, e.g. veterinary medicines, only have small sample sizes so their true variation may not be well represented.

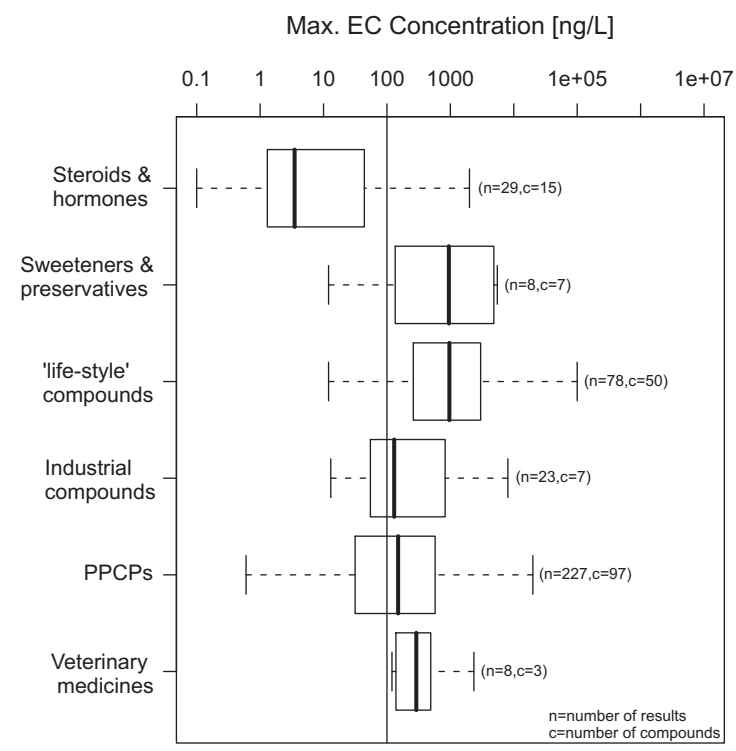

Fig. 3. Boxplot per compound type, adapted from Lapworth et al. (2012)[20] (note the log scale on the $\mathrm{y}$-axis). $\mathrm{n}=$ number of results, $\mathrm{c}=$ number of different compounds for each group. 
Table 1. Summary statistics for maximum concentrations (ng/L) for ECs found by at least 4 studies and their major use [20]

\begin{tabular}{|c|c|c|c|c|c|c|}
\hline Class & Compound & $\mathrm{n}$ & Lowest & Average & Highest & $\mathrm{Use}^{ \pm}$ \\
\hline \multirow[t]{16}{*}{ Pharmaceutical } & Carbamazepine & 23 & 1.64 & 5312 & 99194 & Antiepileptic \\
\hline & Sulfamethoxazole & 15 & 5.7 & 252 & 1110 & Antibiotic \\
\hline & Ibuprofen+ & 14 & 0.6 & 1491 & 12000 & Anti-inflammatory** \\
\hline & Diclofenac & 11 & 2.5 & 121 & 590 & Anti-inflammatory \\
\hline & Clofibric acid $+*$ & 8 & 4 & 1113 & 7300 & Lipid regulator \\
\hline & Paracetamol+ & 8 & 15 & 15142 & 120000 & Analgesic \\
\hline & Ketoprofen & 6 & 3 & 611 & 2886 & Anti-inflammatory \\
\hline & Triclosan & 6 & 7 & 509 & 2110 & Antibiotic \\
\hline & Iopamidol & 5 & 130 & 760 & 2400 & X-ray contrast media \\
\hline & Lincomycin & 5 & 100 & 188 & 320 & Antibiotic \\
\hline & Propyphenazone & 5 & 15 & 553 & 1250 & Analgesic \\
\hline & Sulfamethazine & 5 & 120 & 298 & 616 & Veterinary medicine \\
\hline & DEET & 4 & 454 & 2251 & 6500 & Insect repellent \\
\hline & Phenazone & 4 & 25 & 1503 & 3950 & Analgesic \\
\hline & Primidone & 4 & 110 & 3380 & 12000 & Barbiturate \\
\hline & Salicylic acid+* & 4 & 43 & 418 & 1225 & Analgesic \\
\hline \multirow[t]{2}{*}{ Life-style } & Caffeine & 14 & 13 & 9774 & 110000 & Diuretic \\
\hline & Cotinine* & 4 & 60 & 173 & 400 & Stimulant \\
\hline \multirow[t]{4}{*}{ Industrial } & Bisphenol A+ & 9 & 470 & 2527 & 9300 & Plasticiser \\
\hline & Nonylphenol+* & 6 & 1500 & 23088 & 84000 & Detergent \\
\hline & Galoxalide+ & 5 & 6 & 4984 & 23000 & Fragrance \\
\hline & $\begin{array}{l}\text { Tris(2-chloroethyl) } \\
\text { phosphate }\end{array}$ & 4 & 495 & 656 & 740 & Fire retardant \\
\hline \multirow[t]{2}{*}{ Hormone } & Estrone+* & 6 & 0.1 & 9 & 45 & Estrogenic hormone \\
\hline & 17b-Estradiol+ & 4 & 0.79 & 31 & 120 & Estrogenic hormone \\
\hline
\end{tabular}

Table 1 summarises the lowest, average and highest maximum concentrations found in groundwaters for individual ECs that were reported in at least four separate studies. Maximum concentrations for the most commonly detected compounds in groundwater were reported in the range 40-104 ng/L. The six most commonly reported compounds globally were carbamazepine, sulfamethoxazole, ibuprofen, caffeine, diclofenac and bisphenol A. There is no clear relationship between average or highest maximum concentration and frequency. The overall loading on the environment, unsaturated zone transport time, toxicity to microbes and other physical 
properties such as charge, size and functionality are all important factors in controlling the fate of ECs in the environment and their occurrence in groundwater.

A small number of pharmaceuticals have been detected in treated drinking water: carbamazepine and sulfamethoxazole [161-2], tylosin (veterinary antibiotic) [54], estrone (metabolite); $17 \alpha$ - and 17 $\beta$-estradiol and ethinylestradiol [163].

Compared to surface water samples the groundwaters across Europe were found to be less contaminated, with a $25 \%$ frequency of detection for all compounds [164]. The results compared well for the USA in terms of frequency for selected compounds $[46,103]$. Table 2 shows the frequency and summary statistics for a selection of pharmaceuticals, industrial compounds and caffeine that have been detected in both regional and national scale groundwater reconnaissance studies. It should be noted that site selection criteria and sample numbers are not consistent across the studies and there is considerable variation in the frequency of detects for commonly detected compounds between studies carried out in different countries and within the same country.

The five most commonly reported pharmaceuticals in this study have all been licensed for use in the USA for more than two decades, and in the case of carbamazepine, sulfamethoxazole, ibuprofen and clofibrate, more than three decades. Their frequent reporting is likely due to a long history of use. Their widespread occurrence in regional studies could also be because they have had sufficient time to travel through the unsaturated zone, and to their prolonged release to the environment, particularly during the 1970s and 1980s when water treatment processes were less able to attenuate these contaminants. Equally, more recently introduced pharmaceuticals may not be observed in groundwater bodies for some years due to unsaturated zone travel times.

\section{$5 \quad$ Challenges}

\subsection{Identifying the Next Emerging Contaminants}

The first challenge will be to identify the chemicals which potentially will become dangerous in the future and minimise the potential threat to groundwater, and to its receptors. To evaluate this threat the scientific community will need to identify new groundwater pollutants and their sources and develop methods to measure them in a variety of matrices down to trace levels. This will allow the determination of the environmental occurrence of these potential contaminants, the characterisation of their sources and pathways that determine release to the aqueous environment and definition and quantification of the processes that determine their transport and fate through the environment. 
Table 2. ECs detected in reconnaissance studies [20]

\begin{tabular}{|c|c|c|c|c|c|}
\hline Compound & Country/Region & Freq. (\%) & Max & Samples & Reference \\
\hline \multirow[t]{6}{*}{ Sulfamethoxazole } & Europe & 24.2 & 38 & 164 & {$[164]$} \\
\hline & USA(a) & 23.4 & 1110 & 47 & [43] \\
\hline & Switzerland & 18 & 48 & 100 & {$[165]$} \\
\hline & France & 18 & 18 & 147 & [166] \\
\hline & Germany & 10 & 410 & 105 & [126] \\
\hline & USA (b) & 0.41 & 170 & 1231 & [167] \\
\hline \multirow[t]{6}{*}{ Ibuprofen } & Europe & 6.7 & 395 & 164 & [164] \\
\hline & USA & 2.1 & 3110 & 47 & [43] \\
\hline & France & 0.5 & 7 & 209 & {$[166]$} \\
\hline & UK & 0.3 & 290 & 2644 & [168] \\
\hline & Switzerland & 0 & $<\mathrm{LQ}$ & 47 & [165] \\
\hline & Germany & 0 & $<\mathrm{LQ}$ & 105 & [126] \\
\hline \multirow[t]{6}{*}{ Carbamazepine } & Europe & 42.1 & 390 & 164 & [164] \\
\hline & France & 42 & 167 & 218 & [166] \\
\hline & Switzerland & 19 & 45 & 47 & [165] \\
\hline & Germany & 12 & 900 & 105 & [126] \\
\hline & USA & 1.5 & 420 & 1231 & [167] \\
\hline & UK & 1.2 & 3600 & 2644 & [168] \\
\hline \multirow[t]{3}{*}{ Nonylphenol } & Austria & 69 & 1500 & 111 & [169] \\
\hline & Europe & 11 & 3850 & 164 & [164] \\
\hline & Denmark & 1.1 & 4200 & 860 & [170] \\
\hline \multirow[t]{4}{*}{ Bisphenol A } & Austria & 59 & 930 & 110 & [169] \\
\hline & Europe & 39.6 & 2299 & 164 & [164] \\
\hline & USA & 29.8 & 2550 & 47 & [43] \\
\hline & UK & 8 & 9300 & 2644 & {$[168]$} \\
\hline \multirow[t]{4}{*}{ Caffeine } & Europe & 82.9 & 189 & 164 & [164] \\
\hline & UK & 27 & 4500 & 2644 & [168] \\
\hline & USA(a) & 12.8 & 130 & 47 & [43] \\
\hline & USA(b) & 0.24 & 290 & 1231 & [167] \\
\hline
\end{tabular}

Daughton (2004) raises a number of issues relating to the management of emerging contaminant problems which represent major challenges for both the science community and those with responsibilities for risk assessment and managing pollution [7], namely:

- growing questions about pervasiveness and significance of low level effects, and awareness that there may be effects from concentrations below the toxic limit

- issues that may occur from inadequate water infrastructure and decentralised water use 
- consequences of water reuse and artificial groundwater recharge

- pollution prevention, early warning programmes, monitoring programmes, use of pollutants as indicators,

- changing consumer behaviour and risk perception, communicating risk, new precautionary principles.

\subsection{Setting Appropriate Standards}

The WFD and the GD $[22,24]$ require the setting of threshold values (TVs) for all pollutants which put the groundwater body at risk of failing to achieve good status. In setting TVs the following criteria must be considered: the extent of interaction of groundwater and ecosystems and the toxicology, dispersion tendency, persistence and bioaccumulation potential. For ECs the establishment of TVs, if necessary, will be a challenging task and require much better understanding of key properties and their distribution and behaviour in groundwater. As such, for individual compounds, this is likely to be a lengthy process.

\subsection{Improving Monitoring and Characterisation}

Techniques need to be sought to enable the wide range of potential new and existing contaminants to be detected in groundwater and surface water. These could include assays where the toxicological activity of the contaminant loading is measured rather than the identity of individual compounds, for example targeted bioassays. Passive samplers have also been suggested [171-172], although there are obvious difficulties in applying these cumulative sampling methods within a regulatory framework. The combined use of passive samplers and a series of bioassays have been effective in monitoring polar organics in effluents [173]. Biosensors are only one example of possible alternative approaches to monitoring ECs in groundwater.

Basic physical and chemical parameters, such as octanol-water partition coefficients, are lacking for many ECs. In the absence of directly measured parameters, molecular topology approaches have been used for decades to estimate environmental risk from chemical structure alone [174-175].

\section{Conclusions}

1. A wide range of organic micropollutants is now being detected in the aqueous environment world-wide. These include pesticides, pharmaceuticals, industrial additives and by-products, PCPs and fragrances, water treatment by products, flame/fire retardants and surfactants, as well as caffeine and nicotine metabolites and hormones. 
2. Environmentally significant concentrations $\left(10^{2}-10^{4} \mathrm{ng} / \mathrm{L}\right)$ of a range of ECs are being detected in groundwaters globally as a result of both recent and historical activities. Carbamazepine, sulfamethoxazole, ibuprofen, bisphenol A and caffeine are the most widely reported compounds. Many of these ECs are among the highest priority substances for treatment and regulation both in terms of their potential environmental and human health effects, toxicity and endocrine disruption.

3. Compared to other freshwater resources the occurrence of ECs in groundwater is poorly characterised. Many studies have been biased towards potentially contaminated sites so their actual distribution in groundwater remains largely unknown. So far site-specific research has been directed towards waste water point sources, there is currently limited understanding of the risk of groundwater pollution from more diffuse sources such as biosolids and urban sewage leakage.

4. Groundwaters may continue to be polluted with ECs for decades as a result of long unsaturated zone/groundwater residence times, although this also means there is a high potential for natural attenuation. This review has highlighted the fact that degradates, for example from pesticides, are often found more frequently and in greater concentrations than their parent and reinforces the need to monitor and regulate for degradates of ECs as well as parent compounds. However, detecting ECs in the aquatic environment, particularly in groundwater, will continue to be a challenge due to technical limitations (relatively high detection limits), and cost.

5. Regulation of these compounds in groundwater and the wider environment will be a challenging task and require much better understanding of key contaminant properties as well as their distribution and behaviour in groundwater. The challenges include identifying new emerging compounds, setting appropriate standards, and applying novel monitoring methods.

\section{References}

[1] H-J. Stan and M. Linkerhagner."Identification of 2-(4-chlorphenoxy)-2-methylpropionic acid in groundwater with GC-AED and GC-MS,"Vom Wasser, vol 79, pp. 75-88, 1992.

[2] H-J. Stan et al.,"Occurrence of clofibric acid in the aquatic system - is the use of human medical care the source of the contamination of surface, ground and drinking water?," Vom Wasser, vol 83, pp.57-68, 1994.

[3] B. Halling-Sørensen et al, "Occurrence, fate and effects of pharmaceutical substances in the environment - a review,"Chemosphere, vol 36, pp. 357-93, 1998.

[4] C.G. Daughton and T.A.Ternes,"Pharmaceuticals and personal care products in the environment: agents of subtle change?'Environmental Health Perspectives, vol 107, pp. 907-38, 1999. 
[5] R.P. Schwarzenbach et al.,"The challenge of organic micropollutants in aquatic systems,"Science, vol. 313, pp.1072-7, 2006.

[6] K, Kümmerer, “The presence of pharmaceuticals in the environment due to human use- present knowledge and future challenges," Journal of Environmental Management, vol 90, 2354-66. 2009.

[7] A. Pal et al.,"'Impacts of emerging organic contaminants on freshwater resources: Review of recent occurrences, sources, fate and effects,"Science of the Total Environment, vol. 408, pp. 6062-9, 2010.

[8] C.G. Daughton,"Non-regulated water contaminants: emerging research," Environmental Impact Assessment, vol. 24, pp. 711-32 2004

[9] M.E. Lindsey et al., "Analysis of trace levels of sulfonamide and tetracycline antimicrobials in groundwater and surface water using solid-phase extraction and liquid chromatography/mass spectroscopy,"Analytical Chemistry, vol. 73, pp. 4640-4646, 2001.

[10] M. Petrović and D.Barceló,"Application of liquid chromatography/quadruple time-offlight mass spectrometry (LC-QqTOF-MS) in the environmental analysis,"Journal of Mass Spectometry, vol. 41, pp. 1259-1267, 2006.

[11] S.D. Richardson and T.A.Ternes, "Water analysis: emerging contaminants and current issues,"Analytical Chemistry, vol. 83, pp. 4614-4648, 2011.

[12] M. Hilton, et al. "Targeted monitoring programme for pharmaceuticals in the aquatic environment," UK Environment Agency R\&D Technical Report P6-012/6, 2003

[13] G. Huschek et al.,"Environmental risk assessment of medicinal products for human use according to European Commission recommendations,"Environmental Toxicology, vol. 19, pp. 226-40, 2004.

[14] K. Fent et al.,"'Ecotoxicology of human pharmaceuticals," Aquatic Toxicology, vol. 76, pp. 122-59. 2006.

[15] M. Crane et al.," Chronic aquatic environmental risks from exposure to human pharmaceuticals," Science of the Total Environment, vol. 367, pp. 23-41, 2006.

[16] J-P. Besse and J. Garric,"Human pharmaceuticals in surface waters. Implementation of a prioritization methodology and application to the French situation," Toxicology. Letters, vol. 176, pp. 104-23, 2008.

[17] M.D. Celiz, et al.,"Pharmaceutical metabolites in the environment: analytical challenges and ecological risks,"Environmental and Toxicological Chemistry, vol. 28, pp. 2473-84. 2009.

[18] C. Houtman, "Emerging contaminants in surface waters and their relevance for the production of drinking water in Europe," Journal of Intergrative Environmental Science, vol. 7, pp. 271-95, 2010.

[19] K.E. Murray,'Prioritizing research for trace pollutants and emerging contaminants in the freshwater environment," Environmental Pollution, vol. 158, pp. 3462-71, 2010.

[20] D. J. Lapworth et al.,"Emerging organic contaminants in groundwater: A review of sources, fate and occurrence,"Environmental Pollution, vol.163, pp.287-303, 2012.

[21] M. C. Kavanaugh,"Unregulated and emerging chemical contaminants: technical and institutional challenges," Proceedings of the Water Environmental Federation WEFTEC, Session 1-10, pp.1-19. 2003.

[22] EC. Groundwater Directive 2006/118/EC

[23] USEPA (2006) Edition of the Drinking Water Standards and Health Advisories. United States Environmental Protection Agency. Available: http://epa.gov/waterscience/criteria/drinking/dwstandards.pdf

[24] EC. Water Framework Directive - 2000/60/EC

[25] EC. Drinking Water Directive 98/83/EC.

[26] EC. Plant Protection Products Directive 91/414/EEC

[27] EC. Biocidal Products Directive 98/8/EC 
[28] EC. Environmental Quality Standards Directive 2008/105/EC (also known as the Priority Substances Directive)

[29] EC. Review of priority substances under the WFD, COM(2011)876

[30] USEPA (2009) Contaminant Candidate List 3 (CCL3). United States Environmental Protection Agency Available: http://water.epa.gov/scitech/drinkingwater/dws/ccl/ccl3.cfm

[31] J. Bauld, "Groundwater quality: human impact on a hidden resource ". In: Hydrology and Water Resources Symposium 1996: Water and the Environment; National conference publication (Institution of Engineers, Australia); no. 96/05, p p. 143-7. 1996

[32] M E. Close, "Survey of pesticides in New Zealand groundwaters," New Zealand Journal of Marine and Freshwater Research, vol. 30 (4), pp. 455-61, 1994.

[33] D. W. Kolpin et al., "Pesticides in groundwater of the United States, 1992-1996," Ground Water, vol. 38 (6), pp. 858-63, 1998.

[34] N.H. Spliid and B. Køppen," Occurrence of pesticides in Danish shallow groundwater," Chemosphere, vol. 37(7), 1307-16, 1998.

[35] W. Tappe et al., "Diffuse atrazine pollution in German aquifers," Biodegradation, vol.13 (1),pp. 3-10, 2002.

[36] D. Walls et al., "Pesticides in groundwater in Britain," International Journal of Environmental Health Research, vol.6 (1), 55-62, 1996.

[37] Water UK, "Metaldehyde briefing" 2011. Available: http://www.water.org.uk/home/policy/positions/metaldehyde-briefing

[38] S. Galassi. "Risk assessment for pesticides and their metabolites in water," International Journal of Environmental Analytical Chemistry, vol.65, pp. 331-44, 1996.

[39] D.W. Kolpin et al., "Finding minimal herbicide concentrations in ground water? Try looking for their degradates," Science of the Total Environment, vol. 248, pp.115-122, 2000.

[40] D.W. Kolpin et al., "Degradates provide insight to spatial and temporal trends of herbicides in ground water". Ground Water, vol.42, pp.601-8, 2004.

[41] D.J. Lapworth and D.C. Gooddy," Source and persistence of pesticides in a semiconfined chalk aquifer of southeast England," Environmental Pollution, vol. 144, pp.1031-44, 2006.

[42] M.L.Richardson and J.M. Bowron. "The fate of pharmaceutical chemicals in the aquatic environment," Journal of Pharmacology, vol. 37, pp. 1-12, 1985.

[43] K. Barnes et al.,"A national reconnaissance of pharmaceuticals and other organic wastewater contaminants in the United States I. Groundwater," Science of the Total Environment, vol. 402, pp. 192-200, 2008.

[44] K J. Miller and J., Meek"Helena Valley ground water: pharmaceuticals, personal care products, endocrine disruptors (PPCPs) and microbial indicators of faecal contamination”. Montana Bureau of Mines and Geology, Open File Report 532. 2006

[45] A. Nikolaou et al., "Occurrence patterns of pharmaceuticals in water and wastewater environments." Analytical \& Bioanalytical Chemistry, vol. 387, pp. 1225-34, 2007.

[46] S, Pérez and D. Barceló 2007. "Fate and occurrence of X-ray contrast media in the environment." Analytical \& Bioanalytical Chemistry, vol. 387, pp. 1235-46.

[47] E.Vulliet and C. Cren-Olive,"Screening of pharmaceuticals and hormones at the regional scale, in surface and groundwaters intended to human consumption," Environmental Pollution, vol. 159, pp. 2929-34, 2011.

[48] A.J. Watkinson, "The occurrence of antibiotics in an urban watershed: from wastewater to drinking water," Science of the Total Environment, vol. 407, pp. 2711-23, 2009.

[49] I.J., Buerge,et al.,"Occurrence and fate of the cyclostatic drugs cyclophosphamide and iphosphamide in wastewater and surface waters," Environmental Science \& Technology, vol. 40, pp. 7242-50, 2006. 
[50] A.C. Johnson," Do cytotoxic chemotherapy drugs discharged into rivers pose a risk to the environment and human health? An overview and UK case study," Journal of Hydrology, vol. 348, pp. 167-75, 2008.

[51] Z. Moldovan." Occurrences of pharmaceutical and personal care products as micropollutants in rivers from Romania," Chemosphere, vol.64, pp.1808-17, 2006

[52] A.C. Singer et al., Potential risks associated with the proposed widespread use of Tamiflu. Environmental Health Perspectives, vol. 115, pp.102-6, 2007.

[53] B. Kasprzyk-Hordern et al., "The occurrence of pharmaceuticals, personal care products, endocrine disruptors and illicit drugs in surface water in South Wales, UK. Water Research, vol. 42,pp. 3498-518, 2008.

[54] E. Zuccato, et al., "Presence of therapeutic drugs in the environment," Lancet, vol. 355, pp. 1789-90, 2000.

[55] E Godfrey et al.,"Pharmaceuticals in on-site sewage effluent and ground water, Western Montana," Ground Water, vol.45, pp. 263-71, 2007.

[56] R.L Seiler et al., Caffeine and pharmaceuticals as indicators of waste water contamination in wells. Ground Water, vol. 37, pp. 405-410, 1999.

[57] G. Teijon et al.,"Occurrence of emerging contaminants, priority substances $(2008 / 105 / C E)$ and heavy metals in treated wastewater and groundwater at Depurbaix facility (Barcelona,Spain)," Science of the Total Environment, vol.408, pp. 3584-95. 2010.

[58] Van Stempvoort et al., "Artificial sweeteners as potential tracers in groundwater in urban environments," Journal of Hydrology, vol. 401, pp. 126-33. 2011.

[59] I.J. Buerge et al.,"Ubiquitous occurrence of the artificial sweetener acesulfame in the aquatic environment: an ideal chemical marker of domestic wastewater in groundwater," Environmental Science \& Technology, vol. 43, pp. 4381-5, 2009.

[60] A. Lindström et al.,"Occurrence and environmental behaviour of the bactericide triclosan and its methyl derivative in surface waters and in wastewater," Environmental Science \& Technology, vol. 36, pp. 2322-9, 2002.

[61] Y. Horii et al.,"Occurrence and fate of polycyclic musks in wastewater treatment plants in Kentucky and Georgia, USA," Chemosphere, vol. 68, pp. 2011-20, 2007.

[62] I.J. Buerge et al. Behaviour of the polycyclic musks HHCB and AHTN in lakes, two potential anthropogenic markers for domestic wastewater in surface waters. Environmental Science \& Technology, vol. 37, pp. 5636-44, 2003.

[63] H Fromme, et al.,"Polycyclic musk fragrances in different environmental compartments in Berlin (Germany)." Water Research, vol. 35, pp.121-8, 2001.

[64] T.Heberer,"Occurrence, fate, and assessment of polycyclic musk residues in the aquatic environment of urban areas - A review,"Acta Hydrochimica Hydrobiologica, vol.30, pp. 227-43, 2002.

[65] H-K Jeon et al., "Simultaneous determination of benzophenone-type UV filters in water and soil by gas chromatography-mass spectrometry," Journal of Chromatography A, vol. 1131, pp.192-202, 2006.

[66] P.Garrett et al., MTBE as a ground water contaminant. NWWA/API Conference on Petroleum Hydrocarbons and Organic Chemicals in Ground Water: Prevention, Detection and Restoration. National Water Well Association, Dublin, Ohio, Houston, Texas, pp. 227-38, 1986.

[67] M.J. Moran et al., "MTBE and gasoline hydrocarbons in ground water of the United States". Ground Water, vol. 43, pp. 615-27, 2005

[68] M.J. Moran et al., 2006. "Chlorinated solvents in groundwater of the United States," Environmental Science \& Technology, vol. 41, pp. 74-81.

[69] A.Verliefde et al.,"Priority organic micropollutants in water sources in Flanders and the Netherlands and assessment of removal possibilities with nanofiltration,"

Environmental Pollution, vol. 146, pp. 281-289, 2007. 
[70] A. Abe, "Distribution of 1,4-dioxane in relation to possible sources in the water environment," Science of the Total Environment, vol. 227, pp. 41-7, 1999.

[71] G. Giger,"Benzotriazole and tolyltriazole as aquatic contaminants. 1. Input and occurrence in rivers and lakes," Environmental Science \& Technology.vol. 40, pp 718692, 2006.

[72] D. Voutsa, et al.,"Benzotriols, alkylphenols and bisphenol A in municipal wastewaters and the Glatt River, Switzerland," Environmental Science \& Pollution Research, vol. 13 , pp. 333-41, 2006.

[73] ENDS. "River dioxins increased by triclosan," ENDS Rep, vol.425:32. 2010.

[74] M. Mezcua, et al.,"Evidence of 2,7/2,8-dibenzodichloro-p-dioxin as a photodegradation product of triclosan in water and wastewater samples," Analytica Chimica Acta, vol. 524, pp. 241-7, 2004.

[75] S. Jobling et al., "A variety of environmentally persistent chemicals, including some phthalate plasticizers, are weakly estrogenic," Environmental Health Perspective, vol.103, pp. 582-7, 1995.

[76] G.A. Boorman, "Drinking water disinfection byproducts: review and approach to toxicity evaluation," Environmental Health Perspectives, vol. 107, pp. 207-17, 1999.

[77] WA Mitch et al.,"N-Nitrosodimethylamine (NDMA) as a drinking water contaminant: A review," Environmental Engineering Science, vol. 20, pp. 389-404, 2003.

[78] F. Rahman et al.,"Polybrominated diphenyl ether (PBDE) flame retardants," Science of the Total Environment, vol.275, pp. 1-17, 2001.

[79] E.D. Weil,"A systems approach to flame retardancy and comments on mode of action," Polymer Degradation Stability, vol. 54, pp. 125-36, 1996.

[80] S. González, and D. Barceló, “Advanced liquid chromatography-mass spectrometry (LC-MS) methods applied to wastewater removal and the fate of surfactants in the environment.”TrAC , vol. 26 ( 2), pp. 116-24, 2007.

[81] J. Montgomery-Brown, and M. Reinhard,"Occurrence and behaviour of alkylphenol polyethoxylates in the environment," Environmental Engineering Science, vol. 20, pp.471-86, 2003

[82] A, Soares et al.,"Nonylphenol in the environment: A critical review on occurrence, fate, toxicity and treatment in wastewaters," Environment International, vol. 34,pp. 1033-49, 2008

[83] S.D. Richardson,"Water analysis: emerging contaminants and current issues,"Analytical Chemistry, vol.79, pp. 4295-324, 2007.

[84] L Ahrens, Polyfluorinated compounds in waste water treatment plant effluents and surface waters along the River Elbe, Germany. Marine Pollution Bulletin,vol. 58, pp. 1326-33, 2009.

[85] P.A. Lara-Martín, "Occurrence of alkyltrimethylammonium compounds in urban estuarine sediments: Behentrimonium as a new emerging contaminant," Environmental Science \& Technology, vol. 44, pp. 19, 7569-75, 2010.

[86] H.C. Poynton and C.D. Vulpe,"Ecotoxicogenomics: emerging technologies for emerging contaminants,"Journal of the American Water Resources Association, vol 45, pp. 83-95, 2009.

[87] K. Harada, et al.,"Perfluorooctane sulfonate contamination of drinking water in the Tama River, Japan: Estimated effects on resident serum levels," Bulletin Environmental Contamination Toxicology, vol. 71, pp. 31-6, 2003.

[88] N. Saito,"Perfluorooctane sulfonate concentrations in surface water in Japan. Archives Environmental Contamination Toxicology, vol. 45, pp. 149-58, 2003.

[89] A.C. Johnson,"Estimating steroid oestrogen inputs into activated sludge treatment works and observations on their removal from the effluent. Science of the Total Environment, vol. 256, pp.163-73, 2000. 
[90] L. Standley et al., "Wastewater-contaminated groundwater as a source of endogenous hormones and pharmaceuticals to surface water ecosystems," Environmental \& Toxicological Chemistry, vol. 27, pp. 2457-68, 2008.

[91] Z.-h. Liu et al.,"A review of phytoestrogens: Their occurrence and fate in the environment," Water Research, vol. 44, pp. 567-77, 2010.

[92] P.T.P. Thi et al."Environmental fate and toxicity of ionic liquids: A review," Water Research, vol.44, pp. 352-72, 2010.

[93] A.B.A. Boxall,"Review of veterinary medicines in the environment" Environment Agency, Bristol, 2002.

[94] O.A.H. Jones et al.,"Aquatic environmental assessment of the top 25 English prescription pharmaceuticals," Water Research, vol.36, pp. 5013-22, 2002.

[95] M. Stuart, et al.,"'Review of risk from potential emerging contaminants in UK groundwater," Science of the Total Environment, vol. 416, pp. 1-21, 2012.

[96] B.O. Clarke and S.R. Smith,."'Review of "emerging' organic contaminants in biosolids and assessment of international research priorities for the agricultural use of biosolids," Environment International, vol. 37, pp. 226-47, 2011.

[97] A.K. Sarmah, et al., "A global perspective on the use, sales, exposure pathways, occurrence, fate and effects of veterinary antibiotics (Vas) in the environment.," Chemosphere, vol. 65, pp. 725-759, 2006.

[98] X. Hu et al."Occurrence and source analysis of typical veterinary antibiotics in manure, soil, vegetables and groundwater from organic vegetable bases, northern China," Environmental Pollution, vol. 158, pp. 2992-98, 2010.

[99] I.J. Buerge et al.,"Saccharin and other artificial sweeteners in soils: estimated inputs from agriculture and households, degradation, and leaching to groundwater," Environmental Science \& Technology, vol. 45, pp. 615-21, 2011.

[100] M.J. Focazio et al., "A national reconnaissance for pharmaceuticals and other organic wastewater contaminants in the United States - ii) Untreated drinking water sources. Science of the Total Environment, vol. 402, pp. 201-216, 2008.

[101] K. K. Barnes et al., "Pharmaceuticals and other organic waste water contaminants within a leachate plume down gradient of a municipal landfill,"Ground Water Monitoring \& Remediation, vol.24, pp.119-26, 2004.

[102] D.J. Lapworth et al.,"Understanding groundwater, surface water and hyporheic zone biogeochemical processes in a Chalk catchment using fluorescence properties of dissolved and colloidal organic matter," Journal of Geophysical Research, vol 114, 10, pp. 10, 2009.

[103] J.E. Drewes,"Ground water replenishment with recycled water - water quality improvements during managed aquifer recharge," Ground Water, vol. 47, pp 502-5, 2009.

[104] B Mueller et al., "Quantification of exchange rates between groundwater and surface water applying pharmaceutical compounds - the Nuthegraban case," Geophysical Research Abstracts,vol.13, EGU2011-2257, 2011.

[105] O Lev et al. I., "Quantitative evaluation of tracers for quantification of wastewater contamination of potable water sources. Geophysical Research Abstracts, vol.13, EGU2011-5882, 2011.

[106] J.B. Ellis, "Pharmaceutical and personal care products (PPCPs) in urban receiving waters" Environmental Pollution, vol. 144, pp. 184-9, 2006.

[107] G. Hamscher and J. Hartung, "Veterinary antibiotics in dust: sources, environmental concentrations, and possible health hazards,".In: Kümmerer K., editor. Pharmaceuticals in the environment. Springer-Verlag, Berlin, 2008.

[108] K. Bester et al., "Sources and mass flows of xenobiotics in urban water cycles-an overview on current knowledge and data gaps," Water Air \& Soil Pollution Focus, vol. 8, pp. 407-23, 2008. 
[109] S.T. Glassmeyer et al.,"Transport of chemical and microbial contaminants from known wastewater discharges: potential for use as indicators of human fecal contamination," Environmental Science \& Technology, vol. 39, pp.5157-69, 2005.

[110] T. Heberer and D. Feldmann, "Contribution of effluents from hospitals and private households to the total loads of diclofenac and carbamazepine in municipal sewage effluents-modeling versus measurements," Journal of Hazardous Materials, vol. 122, pp. 211-8, 2005.

[111] P. Adler,"Vorkommen natürlicher und synthetischer östrogener Steroide in Wässern des süd- und mitteldeutschen Raumes," Acta Hydrochimica Hydrobiologica, vol. 29, pp.227-41, 2001.

[112] M. Clara et al.,"Carbamazepine as a possible anthropogenic marker in the aquatic environment : investigation on the behaviour of carbamazepine in wastewater treatment during groundwater infiltration," Water Research, vol.38, pp. 947-54, 2004.

[113] J.E.Drewes et al., "Fate of pharmaceuticals during groundwater recharge." Ground Water Monitoring \& Remediation, vol. 23, pp. 64-72, 2003.

[114] G. Gasser et al.,"Quantitative evaluation of tracers for quantification of wastewater contamination of potable water sources," Environmental Science \& Technology, vol. 44, pp. 3919-25, 2010.

[115] S.T. Glassmeyer, et al., "Environmental presence and persistence of pharmaceuticals: an overview," In: D.S Aga,., editor. Fate of pharmaceuticals in the environment and in water treatment systems. CRC Press, Boca Raton, pp. 3-52, 2008.

[116] S Grünheid et al.,"Removal of bulk dissolved organic carbon (DOC) and trace organic compounds by bank filtration and artificial recharge," Water Research, vol. 39, pp. 3219-28, 2005.

[117] T. Heberer and M. Adam,"Transport and attenuation of pharmaceutical residues during artificial ground water replenishment," Environmental Chemistry, vol. 1, pp. 22-25, 2004.

[118] T. Heberer, et al., "Detection of drugs and drug metabolites in ground water samples of a drinking water treatment plant," Fresenius Environmental Bulletin, vol. 6, pp. 438-43, 1997.

[119] T. Heberer et al., "Occurrence of pharmaceuticals residues in sewage, river, ground and drinking water in Greece and Germany," Symposia: Issues in the analysis of environmental endocrine disruptors, ACS, San Francisco, 2000.

[120] T. Heberer et al.,"Field studies on the fate and transport of pharmaceutical residues in bank filtration," Ground Water Monitoring \& Remediation, vol. 24, pp. 70-77, 2004.

[121] B.G. Katz et al.,"'Groundwater quality impacts from land application of treated municipal wastewater in a large karstic spring basin: Chemical and microbiological indicators," Science of the Total Environment, vol. 407, pp. 2872-86., 2009.

[122] N. Kreuzinger et al., "Investigation on the behaviour of selected pharmaceuticals in the groundwater after infiltration of treated wastewater," Water Science \& Technology, vol.50, pp. 221-228.,2004.

[123] J. Mansell and J.E.Drewes,"Fate of steroidal hormones during soil-aquifer treatment,"Ground Water Monitoring \&Remediation, vol. 24, pp. 94-101, 2004.

[124] G. Pecoranio et al.,"Distribution of volatile organic compounds in Sicilian groundwaters analysed by head space-solid phase micro extraction coupled with gas chromatography mass spectrometry (SPME/GC/MS)," Water Research, vol.43, pp.3563-77, 2008.

[125] M. Rabiet et al.,"Consequences of treated water recycling as regards pharmaceuticals and drugs in surface and ground waters of a medium-sized Mediterranean catchment," Environmental Science \& Technology, vol. 40, pp. 5282-8, 2006.

[126] F. Sacher et al.," Pharmaceuticals in groundwaters Analytical methods and results of a monitoring program in Baden-Württemberg, Germany," Journal of Chromatography A, vol. 938, pp. 199-210, 2001. 
[127] F. Sodré et al., "Occurrence of emerging contaminants in Brazilian drinking waters: A sewage-to-tap issue," Water Air \& Soil Pollution, vol. 206, pp. 57-67, 2009.

[128] S.A. Snyder et al.,"Biologial and physical attenuation of endocrine disruptors and pharmaceuticals: implications for water reuse," Ground Water Monitoring \& Remediation, vol. 24, pp. 108-118, 2004.

[129] A. Putschew et al., Occurrence of triiodinated X-ray contrast agents in the aquatic environment," Science of the Total Environment, vol. 255, pp. 129-134, 2000.

[130] T.A. Ternes and R.Hirsch,"Occurrence and behaviour of X-ray contrast media in sewage facilities and the aquatic environment." Environmental Science \&Technology, vol. 34, pp. 2741-2748, 2000.

[131] M Schulz et al.,"Transformation of the X-ray contrast medium iopromide in soil and biological wastewater treatment," Environmental Science \& Technology, vol. 42, pp. $7207-17,2008$.

[132] P. Verlicchi et al., "Hospital effluents as a source of emerging pollutants: an overview of micropollutants and sustainable treatment options," Journal of Hydrology, vol. 389, pp. 416-28, 2010.

[133] D.G.J. Larsson et al., "Effluent from drug manufactures contains extremely high levels of pharmaceuticals," Journal of Hazardous Materials, vol. 148, pp. 751-5, 2007

[134] G.E Cordy et al., "Do pharmaceuticals, pathogens, and other organic waste water compounds persist when waste water is used for recharge?" Ground Water Monitoring \& Remediation, vol. 24, pp. 58-69, 2004.

[135] M.S. Díaz-Cruz and D. Barceló,"Trace organic chemicals contamination in ground water recharge," Chemosphere, vol. 72, pp. 333-42, 2008.

[136] J. Greskowiac, et al.,"Modelling seasonal redox dynamics and the corresponding fate of the pharmaceutical residue phenazone during artificial recharge of groundwater," Environmental Science \&. Technology, vol. 40 ( 21), pp. 6615-21, 2006.

[137] S. Bartelt-Hunt et al., "Occurrence of steroid hormones and antibiotic in shallow groundwater impacted by livestock waste control facilities," Journal of Contaminant Hydrology, vol. 123, pp. 94-103, 2010.

[138] K-R Kim et al.,"Occurrence and environmental fate of veterinary antibiotics in the terrestrial environment," Water Air \& Soil Pollution, vol. 214, pp. 163-74, 2011.

[139] E.P. Kolodziej et al., "Dairy wastewater, aquaculture, and spawning fish a sources of steroid hormones in the aquatic environment.," Environmental Science \& Technology, vol.38, pp. 6377-84, 2004.

[140] N. Watanabe et al.,"Environmental occurrence and shallow ground water detection of the antibiotic monensin from dairy farms. Journal of. Environmental Quality, vol. 37, pp. $78-85,2008$.

[141] N. Watanabe et al.,"Use and environmental occurrence of antibiotics in freestall dairy farms with manure forage fields," Environmental Science \& Technology, vol. 44, pp. 6591-600, 2010.

[142] M.E. Stuart and B.A. Klinck,"A catalogue of leachate quality for selected landfills from newly industrialised countries," British Geological Survey Technical Report WC/98/49, Keyworth, 1998

[143] M. Ahel et al.," The impact of contamination from a municipal solid waste landfill (Zagreb, Croatia) on underlying soil. Water Science \& Technology, vol. 37, pp. 203-10, 1998.

[144] M. Ahel, and I. Jelicic,"Occurrence of phenazone analgesics in landfill-leachate polluted groundwater," In: Keith, L.H., Needham, L.L.and Jones-Lepp, T.L. (Eds.), Issues in the Analysis of Environmental Endocrine Disruptors, Proc. ACS Symp. vol. 40 (1), pp. 109-11. Washington, DC. 2000.

[145] W.P. Eckel, et al.,'Pentobarbital found in ground water.," Ground Water, vol. 5, pp. 801-804, 1993. 
[146] J.V. Holm et al., "Occurrence 1993. and distribution of pharmaceutical organic compounds in the groundwater downgradient of a landfill (Grindsted, Denmark)," Environmental Science \&Technology, vol. 28, pp. 1415-20. 1995.

[147] P.M. Buszka et al., "Waste-indicator and pharmaceutical compounds in landfillleachate-affected ground water near Elkhart, Indiana, 2000-2002," Bulletin of Environmental \& Contaminant Toxicology, vol. 82, pp. 653-9, 2009.

[148] D.J. Lapworth et al., "Pesticides in groundwater: some observations on temporal and spatial trends" Water and Environment Journal, vol. 20, pp55-64.

[149] S.A. Parsons, "Pesticide degradates of concern to the drinking water community," AWWA Research Foundation, Denver, 2008.

[150] G. Buttiglieri et al., "Environmental occurrence and degradation of the herbicide nchloridazon," Water Research, vol.43, pp. 2865-73, 2009.

[151] A. Laganà et al.,"Occurrence and determination of herbicides and their major transformation products in environmental waters," Analytica Chimica Acta, vol. 462, pp. 187-98, 2002.

[152] C.S. Jacobsen et al., Emerging contaminants in Danish groundwater, GEUS report, Denmark, 2005

[153] P. Olsen et al.,"Leaching of metribuzin metabolites and the associated contamination of a sandy Danish aquifer," Environmental Science \& Technology, vol.39, pp. 8374-81, 2005.

[154] K. Haarstad and G.H. Ludvigsen,'Ten years of pesticide monitoring in Norwegian ground water," Ground Water Monitoring Review, vol. 27, pp.75-89, 2007.

[155] N. Baran et al., "Hydrodynamic and geochemical constraints on pesticide concentrations in the groundwater of an agricultural catchment (Brevilles, France)," Environmental Pollution, vol.148, pp. 729-38. 2007.

[156] N. Baran et al.,"Agricultural diffuse pollution in a chalk aquifer (Trois Fontaines, France): Influence of pesticide properties and hydrodynamic constraints,"Journal of Hydrology, vol. 35, pp.56-69, 2008.

[157] N.Baran et al.,"Pesticide contamination of groundwater at the scale of a water body: example of the Ariège alluvial plain (France)," Groundwater Protection in the EU, Madrid, pp. 77-83, 2010.

[158] A. Hildebrandt et al., Assessment of priority pesticides, degradation products, and pesticide adjuvants in groundwaters and top soils from agricultural areas of the Ebro river basin. Analytical \& Bioanalytical Chemistry, vol. 387, pp.1459-68, 2007.

[159] T.C. Hancock et al.,"Pesticide fate and transport throughout unsaturated zones in five agricultural settings, USA," Journal of Environmental Quality, vol. 37, pp.1086-100, 2008.

[160] B.W Brooks et al.,"Pharmaceuticals and personal care products: research needs for the next decade," Environmental Toxicology \& Chemistry, vol. 28, pp. 2469-72, 2009.

[161] A.M.M.Stolker et al.,"Liquid chromatography with triquadrapole or quadrapole-time of flight mass spectrometry for screening and confirmation of residues of pharmaceuticals in water," Analytical \& Bioanalytical Chemistry, vol. 378, pp. 955-63, 2004

[162] P.E. Stackelberg et al.,"Efficiency of conventional drinking water-treatment processes in removal of pharmaceuticals and other organic compounds," Science of the Total Environment, vol. 377, pp. 255-72.

[163] M.H. Kuch and K Ballschmiter,'Determination of endocrine disrupting phenolic compounds and estrogens in surface and drinking water by HRGC-(NCI)-MS in the pg/L range,"Environmental Science \& Technology, vol. 35, pp. 3201-6, 2001.

[164] R. Loos et al.,"Pan-European survey on the occurrence of selected polar organic persistent pollutants in ground water,"Water Research, vol. 44, pp. 4115-26, 2010.

[165] NAQUA, "BAFU 2009: Ergebnisse der Grundwasserbeobachtung Schweiz (NAQUA). Zustand und Entwicklung 2004-2006. Umwelt-Zustand Nr. 0903. Bundesamt für 
Umwelt, Bern. 144 S, 2009.

http://www.bafu.admin.ch/publikationen/publikation/01021/index.html?lang=de

[166] J. Faille,'Vulnérabilité des nappes d'eau souterraine aux pollutions médicamenteuses: aquifer vulnerability to drug pollution [a literature review]. Masters dissertation, Lille polytechnic. (Abstract in English), pp. 19, 2010.

[167] M.S. Fram and K. Belitz, "Occurrence and concentrations of pharmaceutical compounds in groundwater used for public drinking-water supply in California," Science of the Total Environment, vol. 409, pp. 3409-17, 2011.

[168] M.E. Stuart et al.,"Emerging contaminants in groundwater," British Geological Survey Open Report, OR/11/013, 79 pp., 2011.

[169] P. Hohenblum et al.,"Monitoring of selected estrogenic hormones and industrial chemicals in groundwaters and surface waters in Austria," Science of the Total Environment, vol. 333, pp.185-193, 2004.

[170] R.K. Juhler and G. Felding, "Monitoring methyl tertiary butyl ether (MTBE) and other organic micropollutants in groundwater: Results from the Danish National Monitoring Program," Water, Air, \& Soil Pollution, vol. 149, pp. 145-61, 2003.

[171] D.A. Alvarez et al., "Development of a passive, in-situ, integrative sampler for hydrophilic organic compounds in aquatic environments," Environmental \& Toxicological Chemistry, vol. 23, pp. 1640-8, 2004.

[172] F. Stuer-Lauridsen, "Review of passive accumulation devices for monitoring organic micropollutants in the aquatic environment," Environmental Pollution, vol. 136, pp. 03-254, 2005

[173] R. Muller et al., "Combining passive sampling and toxicity testing for evauating mixtures of polar organic chemicals in sewage treatment plant effluent," Journal of Environmental Monitoring, vol. 9, pp. 105-10, 2007.

[174] A. Sabjlic and M. Protic," Molecular connectivity: a novel method for prediction of bioconcentration factor of hazardous chemicals," Chemico-Biological Interactions, vol. 42, pp. 301-10,1982.

[175] W. Meylan, P.H. Howard, and R.S. Boethling," Molecular topology/fragment contribution method for predicting soil sorption coefficients," Environmental Science \& Technology, vol. 26, pp.1560-7, 1992. 